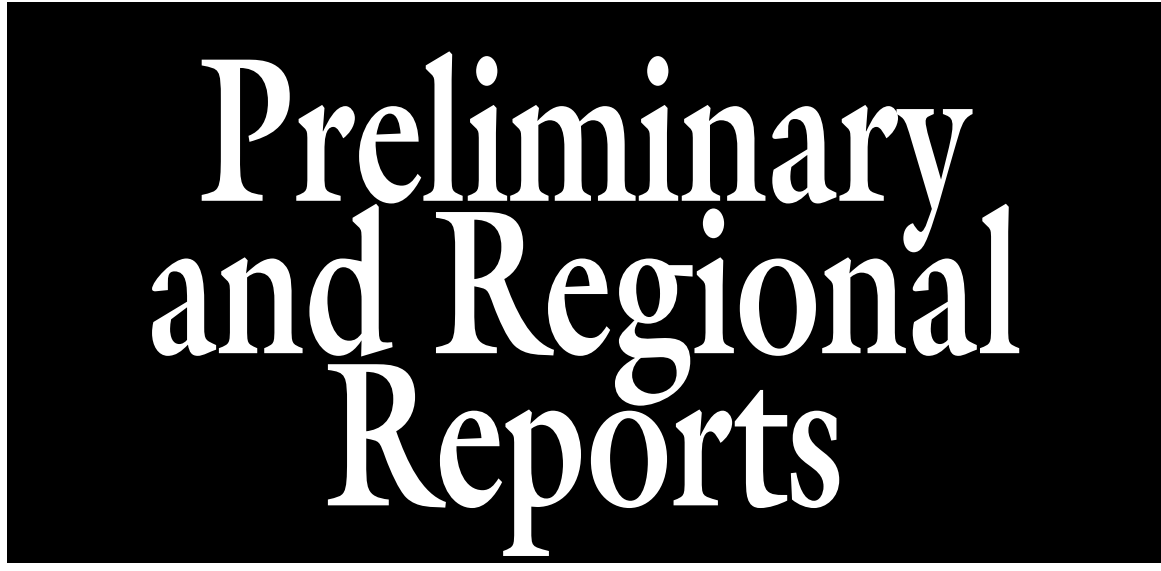

\title{
Suitable Drying Temperature for Preserving Cucurbitacins in Fruit of Wild Cucumber and Wild Watermelon
}

\author{
Kagiso Given Shadung ${ }^{1,3}$, Phatu William Mashela ${ }^{2}$, \\ and Maboko Samuel Mphosi ${ }^{1}$
}

ADDITIONAL INDEX wORDs. Cucumis africanus, Cucumis myriocarpus, degradation, medicinal system, triterpenoid, volatilization, wild cucumber, wild watermelon

\begin{abstract}
Summary. The thermostable cucurbitacin A and B from mature fruit of wild cucumber (Cucumis myriocarpus) and wild watermelon (Cucumis africanus), respectively, are used in product development for various industries. Mature fruit from wild cucumber and wild watermelon suffer from high incidents of postharvest decays. Drying fruit at the recommended temperatures of 30 to $40{ }^{\circ} \mathrm{C}$ for medicinal plants resulted in molds developing on the material, with optimum temperature to prevent decays being at $52{ }^{\circ} \mathrm{C}$. The influence of $52{ }^{\circ} \mathrm{C}$ and higher temperatures on active ingredients in the two fruit had not been documented. The objective of this study, therefore, was to determine the relative effects of increasing drying

temperatures above the $52{ }^{\circ} \mathrm{C}$ standard on concentrations of cucurbitacin $\mathrm{A}$ and $\mathrm{B}$ in fruit of wild cucumber and wild watermelon. Fruit pieces were oven-dried at 52, 60, $70,80,90$, and $100{ }^{\circ} \mathrm{C}$ for 72 hours. Relative to $52^{\circ} \mathrm{C}$, higher temperatures resulted in $25 \%$ to $92 \%$ less cucurbitacin compared with the maximum produced at $60{ }^{\circ} \mathrm{C}$. In contrast, relative to $52{ }^{\circ} \mathrm{C}$, higher temperatures reduced concentrations of cucurbitacin $\mathrm{B}$ by $47 \%$ to $86 \%$. In conclusion, the compromise temperature of $52{ }^{\circ} \mathrm{C}$ for preserving fruit pieces in wild cucumber and wild watermelon from decay should also be viewed as the optimum temperature for preserving cucurbitacin $\mathrm{A}$ and $\mathrm{B}$.
\end{abstract}

$\mathrm{F}$ ruit of wild cucumber and wild watermelon are used in medicinal systems, nutrition, pharmaceutical, cosmetic, and pesticidal industries (Lee et al., 2010; Mashela et al., 2011; Thies et al., 2010; Van Wyk and Wink, 2012; Van Wyk et al., 2002). Fruit of wild cucumber and

\footnotetext{
${ }^{1}$ Limpopo Agro-Food Technology Station, University of Limpopo, Private Bag X1106, Sovenga 0727, South Africa

${ }^{2}$ Green Technologies Research Centre, University of Limpopo, Private Bag X1106, Sovenga 0727, South Africa

${ }^{3}$ Corresponding author. E-mail: kagiso.shadung@ul. ac.za.
}

doi: 10.21273/HORTTECH03400-16

wild watermelon contain cucurbitacin A $\left(\mathrm{C}_{32} \mathrm{H}_{46} \mathrm{O}_{9}\right)$ and cucurbitacin $\mathrm{B}$ $\left(\mathrm{C}_{32} \mathrm{H}_{46} \mathrm{O}_{8}\right)$, respectively (Chen et al.,
2005; Jeffrey, 1978). The two thermostable chemical compounds (Krieger, 2001) are classified as triterpenoids (Chen et al., 2005; Van Wyk and Wink, 2012). Cucurbitacin A, which is soluble in water (Jeffrey, 1978), is unstable and readily oxidises to cucumin $\left(\mathrm{C}_{27}\right.$ $\left.\mathrm{H}_{40} \mathrm{O}_{9}\right)$ and leptodermin $\left(\mathrm{C}_{27} \mathrm{H}_{38} \mathrm{O}_{8}\right)$, whereas the insoluble cucurbitacin $\mathrm{B}$ is stable (Jeffrey, 1978). Fruit of wild cucumber and wild watermelon are seasonal, but cannot be stored in fresh form due to the high incidents of postharvest decays. Mphahlele et al. (2012) identified the causal agent as the acid-loving fungus Penicillium simplicissimum. Usually, fungal decay promotes losses of constituents of the affected organs. Fungi digest food outside its cells by secreting acids and powerful hydrolytic enzymes that decompose complex molecules into simpler compounds that the fungus can absorb and metabolize (Campbell, 1990). Fungal decays have been ameliorated through drying, which had been successfully used to preserve active ingredients in most organs used in various medicinal systems (DansoBoateng, 2013; Diaz-Maroto et al., 2002; Mudau and Ngezimana, 2014; Rocha et al., 2011).

The recommended drying temperature range for various organs in medicinal plants is 30 to $40{ }^{\circ} \mathrm{C}$ (Müller and Heindl, 2006). However, when fruit pieces of the wild cucumber and wild watermelon were dried within the recommended range, most of the cucurbitacin materials were lost to decay, with a blue, bluishgreen, or olive green colors, surrounded by white mycelium and a band of water-soaked tissues that characterize $P$. simplicissimum infection. A preliminary optimum drying temperature to prevent growth of mycelia and, therefore, subsequent decay, was established at $52{ }^{\circ} \mathrm{C}$ (Mashela,

\begin{tabular}{llll}
\hline $\begin{array}{l}\text { Units } \\
\text { To convert U.S. to SI, } \\
\text { multiply by }\end{array}$ & U.S. unit & SI unit & $\begin{array}{l}\text { To convert SI to U.S., } \\
\text { multiply by }\end{array}$ \\
\hline 29.5735 & $\mathrm{fl} \mathrm{oz}$ & $\mathrm{mL}$ & 0.0338 \\
0.3048 & $\mathrm{ft}$ & $\mathrm{m}$ & 3.2808 \\
2.54 & inch(es) & $\mathrm{cm}$ & 0.3937 \\
25.4 & inch $(\mathrm{es})$ & $\mathrm{mm}$ & 0.0394 \\
1 & micron $(\mathrm{s})$ & $\mu \mathrm{m}$ & 1 \\
1 & $\mathrm{mmho} / \mathrm{cm}$ & $\mathrm{dS} \cdot \mathrm{m}^{-1}$ & 1 \\
0.1333 & $\mathrm{~mm} \mathrm{Hg}$ & $\mathrm{kPa}$ & 7.5006 \\
28.3495 & $\mathrm{oz}$ & $\mathrm{g}$ & 0.0353 \\
1 & $\mathrm{ppm}$ & $\mu \mathrm{g} \cdot \mathrm{mL}^{-1}$ & 1 \\
$\left({ }^{\circ} \mathrm{F}-32\right) \div 1.8$ & ${ }^{\circ} \mathrm{F}$ & ${ }^{\circ} \mathrm{C}$ & $\left({ }^{\circ} \mathrm{C} \times 1.8\right)+32$
\end{tabular}


2002 ). However, there was no information on the impact of this and higher temperatures on cucurbitacin A or B concentrations in fruit of wild cucumber and wild watermelon. The objective of this study was to determine the relative effects of increasing drying temperatures above $52{ }^{\circ} \mathrm{C}$ on concentrations of cucurbitacin A and B in fruit of wild cucumber and wild watermelon.

\section{Materials and methods}

STUDY SITE AND RAISING WILD CUCUMBER AND WILD WATERMELON. The study was conducted at the Green Technologies Research Center, University of Limpopo, South Africa (lat. $23^{\circ} 53^{\prime} 10^{\prime \prime} \mathrm{S}$, long. $29^{\circ} 44^{\prime} 15^{\prime \prime}$ E). Soil at the site comprised Hutton sandy loam (65\% sand, $30 \%$ clay, $5 \%$ silt) containing $1.6 \%$ organic carbon, with electrical conductivity of $0.148 \mathrm{dS} \cdot \mathrm{m}^{-1}$ and $\mathrm{pH}$ of 6.5. The hot and dry summers usually have day maximum temperatures ranging from 28 to $38^{\circ} \mathrm{C}$, with mean annual rainfall below $500 \mathrm{~mm}$. Seedlings of wild cucumber and wild watermelon were raised in adjacent separate fields, containing five plots $(1 \times 1 \mathrm{~m})$, each plot with four plants. One experiment evaluated cucurbitacin A from fruit of wild cucumber, whereas the second experiment only evaluated cucurbitacin B from wild watermelon fruit. Each plant was fertilized once using $3 \mathrm{~g}$ of $6.3 \mathrm{~N}-9.4 \mathrm{P}-6.3 \mathrm{~K}$ fertilizer (Omnia, Bryanston, South Africa) and plots irrigated weekly using sprinklers.

EXPERIMENTAL DESIGN AND TREATMENTS. Sixty fruit from each plot were harvested at fruit maturity (Shadung et al., 2015), chopped into pieces, and divided equally into six portions. Each portion per plot was randomly assigned to one of the six forced-air drying ovens (EcoTherm; Labotech, Cape Town, South Africa). The drying treatment ovens were set at $52,60,70,80,90$, or $100{ }^{\circ} \mathrm{C}$ and arranged in a complete randomized design, with five replications. Each drying treatment ran for $72 \mathrm{~h}$ and afterward the samples were ground in a Wiley mill to pass through a $1-\mathrm{mm}$ sieve. Before extraction, samples were stored in hermetically sealed plastic bottles at room temperature.

EXTRACTION AND CUCURBITACINS QUANTIFICATION. A representative subsample of $4 \mathrm{~g}$ dried crude extracts of fruit from each treatment were extracted in closed conical flasks containing $100 \mathrm{~mL}$ methanol and dichloromethane at $\mathrm{l}: \mathrm{l}(\mathrm{v} / \mathrm{v})$ solution inside a rotary evaporator (Rotavapor model R-205; Buchi Labortechnik, Essen, Germany) set at $60 \mathrm{rpm}$ at $40{ }^{\circ} \mathrm{C}$ for $4 \mathrm{~h}$. After extraction, subsamples were concentrated by reducing the volume to $30 \mathrm{~mL}$ under reduced pressure on a rotary evaporator and then $1 \mathrm{~mL}$ aliquot centrifuged at $2422 g_{n}$ for $10 \mathrm{~min}$ before filtering through $0.22-\mu \mathrm{m}$ filter (Miller; Sigma-Aldrich, Johannesburg, South Africa). Concentrations of cucurbitacin were quantified using the isocratic elution high-performance liquid chromatography (Prominence model LC10 AD VP; Shimadzu, Kyoto, Japan) with detection using a diode array detector (CTO-20A; Shimadzu). Quantification was performed in a wide pore reverse phase $\mathrm{Cl} 8(25 \mathrm{~cm} \times$ $4.0 \mathrm{~mm}, 5 \mu \mathrm{m}$ ) column (SigmaAldrich, Milan, Italy) using methanol and deionized water at $2: 3(\mathrm{v} / \mathrm{v})$ solution that served as a mobile phase at a flow rate of $1.0 \mathrm{~mL} \cdot \mathrm{min}^{-1}$ in an oven at $35{ }^{\circ} \mathrm{C}$, with wavelengths monitored at $230 \mathrm{~nm}$ for $43 \mathrm{~min}$. Quantification of cucurbitacin A and $\mathrm{B}$ was accomplished by comparing the retention times and peak areas of subsamples to those of pure (about 98\%) cucurbitacin A and B standards (Wuhan ChemFaces Biochemical Co., Wuhan, China). Standards were dissolved in methanol and prepared in serial dilutions of $0.02,0.04,0.06$, 0.08 , and $1.0 \mu \mathrm{g} \cdot \mathrm{mL}^{-1}$.

Data anAlysis. Cucurbitacin A and $\mathrm{B}$ data were subjected to analysis of variance procedure using SAS software (version 9.2; SAS Institute, Carry, NC). When treatments were significant, the sums of squares were partitioned to determine the percentage contribution of sources of variation to the total treatment variation (TTV) in concentration of cucurbitacins. Mean separation was achieved using Waller-Duncan multiple range test. Unless otherwise stated, only treatment means significant at the probability level of $5 \%$ were discussed.

\section{Results}

Treatment effects. Increasing oven-drying temperatures had highly significant $(P \leq 0.01)$ effects on concentrations of cucurbitacin A and B
(Table 1). Increasing temperatures contributed $65 \%$ and $71 \%$ in TTV of cucurbitacin $\mathrm{A}$ and $\mathrm{B}$ concentrations, respectively.

Relative impact. The highest concentration of cucurbitacin A occurred in fruit dried at $60{ }^{\circ} \mathrm{C}$. The higher temperatures reduced cucurbitacin A by $25 \%$ to $92 \%$. In contrast, temperatures above $52{ }^{\circ} \mathrm{C}$ reduced cucurbitacin B by $28 \%$ to $86 \%$.

GeNERATED MODELS. A quadratic relationship was observed between cucurbitacin $\mathrm{A}$ and $\mathrm{B}$ concentrations and drying temperature with an $R^{2}$ of 0.94 and 0.95 , respectively (Fig. 1).

\section{Discussion}

Concentrations of cucurbitacin A and B triterpenoids (Chen et al., 2005) were inversely related to drying temperature. Others (Du et al., 2003; Hwang et al., 2014) observed that concentrations of ginsenoside (another triterpenoids) from ginseng roots decreased when dried at 40,55 , or $70^{\circ} \mathrm{C}$. Similar findings were noted with the pyrethrins - the monoterpenoids (Morris et al., 2006). Rosmarinic acid and sinenselin (phenolic compounds) from misai kucing (Orthosiphon staminiues), increased with increasing temperature below $40{ }^{\circ} \mathrm{C}$, but decreased when dried at 40,55 , or $70{ }^{\circ} \mathrm{C}$ (Abdullah et al., 2011). Drying bush tea (Athrixia phylicoides) between 45 and $65{ }^{\circ} \mathrm{C}$ reduced total phenolic content when compared with freeze- and shade-drying (Mudau and Ngezimana, 2014).

The reduction of chemical compounds with increasing drying temperature has been attributed to the accelerated degradation of the compounds (Phillips et al., 1960), which depends on the chemical bonds within the chemical compounds (Phillips et al., 1960). In essential oils, for example, drying temperature for oregano (Origanum vulgare ssp. hirtum) was optimized at $40{ }^{\circ} \mathrm{C}$ for 72 h (Novák et al., 2011), whereas at higher temperatures most essential oils were volatilized (Faridah et al., 2010; Radünz et al., 2003). Cucurbitacins are thermostable, with boiling temperatures of cucurbitacin $\mathrm{A}$ and $\mathrm{B}$ being at 731 and $699^{\circ} \mathrm{C}$, respectively, at $760 \mathrm{~mm} \mathrm{Hg}$ (Krieger, 2001). The decrease in cucurbitacin with increasing temperature agreed with observations in other chemical compounds such as ginsenosides and pyrethrins 
Table 1. Responses of sum of squares (SS) for cucurbitacin A and B concentrations from fruit of wild cucumber and wild watermelon, respectively, to different oven-drying temperatures $(n=30)$.

\begin{tabular}{|c|c|c|c|c|c|}
\hline \multirow[b]{2}{*}{ Source } & \multirow[b]{2}{*}{ df } & \multicolumn{2}{|c|}{ Cucurbitacin A } & \multicolumn{2}{|c|}{ Cucurbitacin B } \\
\hline & & SS & $\%$ & SS & $\%$ \\
\hline Treatment & 5 & 79.118 & $65 * *$ & 141.362 & $71 * *$ \\
\hline Error & 24 & 42.039 & 35 & 58.368 & 29 \\
\hline Total & 29 & 121.157 & 100 & 198.729 & 100 \\
\hline
\end{tabular}

**Treatment effects were significant at $P \leq 0.01$.
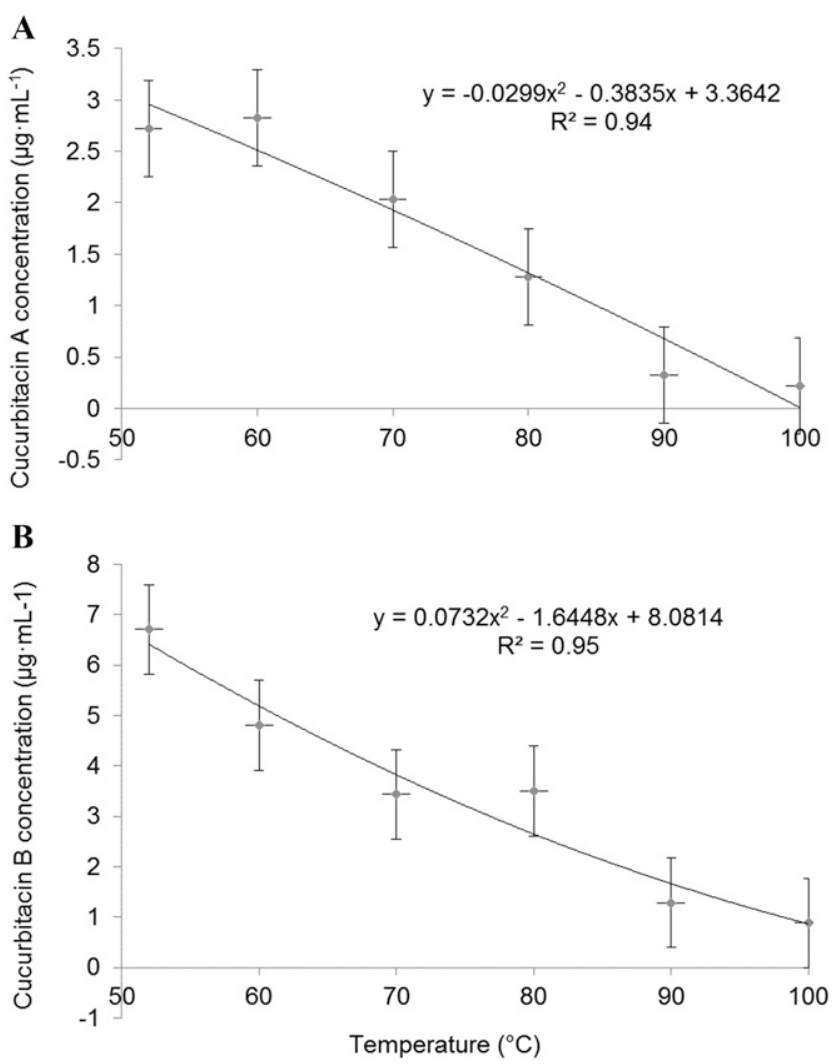

Fig. 1. Relationship between cucurbitacin A and B concentrations from fruit of wild cucumber and wild watermelon, respectively, over increasing drying temperatures at $72-\mathrm{h}$ exposure time; $\left(1.8 \times{ }^{\circ} \mathrm{C}\right)+32={ }^{\circ} \mathrm{F}, 1 \mu \mathrm{g} \cdot \mathrm{mL}^{-1}=1 \mathrm{ppm}$.

(Du et al., 2003; Hwang et al., 2014; Morris et al., 2006).

Drying fruit from wild cucumber and wild watermelon at $52^{\circ} \mathrm{C}$ should be viewed as a compromise temperature for preserving cucurbitacins from P. simplicissimum postharvest decay losses. Optimizing temperature for the retention of cucurbitacins appeared to be above $52{ }^{\circ} \mathrm{C}$ for cucurbitacin $\mathrm{A}$ and below $52{ }^{\circ} \mathrm{C}$ for cucurbitacin $\mathrm{B}$, where fruit are sensitive to decay. However, at $52{ }^{\circ} \mathrm{C}$ it is still necessary to establish the suitable exposure period since the drying periods are inversely proportional to the drying temperatures (Barbieri et al., 2004; Gregory et al., 2005; Hallström and Wimmerstedt, 1983). The proposed optimization of the drying period at $52{ }^{\circ} \mathrm{C}$ could reduce potential losses through degradation and volatilization.

The cucurbitacin concentrations vs. increasing drying temperatures had density-dependent growth (DDG) patterns (Liu et al., 2003; Salisbury and Ross, 1992). Apparently, should drying temperatures start from 25 to $100{ }^{\circ} \mathrm{C}$, cucurbitacin concentrations would go through the three stages of DDG patterns, namely, stimulation, neutral, and inhibition (Mashela et al., 2015). In our study and those of others (Abdullah et al., 2011; Du et al., 2003; Morris et al., 2006), inhibition ranges were exhibited since the drying temperatures were already above the optimization temperatures for the variables. At temperature from 40 to $70{ }^{\circ} \mathrm{C}$, Abdullah et al. (2011) observed that the phenolic compounds tested increased with increasing temperatures, which was a reflection of the stimulation stage (Liu et al., 2003).

\section{Conclusion}

The drying temperature for fruit of wild cucumber and wild watermelon should be retained at $52{ }^{\circ} \mathrm{C}$ as a compromise against decay at lower drying temperatures. However, it would be necessary to optimize the exposure period for drying fruit of wild cucumber and wild watermelon to ensure optimum retention of cucurbitacin $\mathrm{A}$ and $\mathrm{B}$.

\section{Literature cited}

Abdullah, S., M.S. Ahmad, A.R. Shaari, H.M. Johar, and N.F.M. Noor. 2011. Drying characteristics and herbal metabolites composition of misai kucing (Orthosiphon staminues Benth.) leaves. Intl. Conf. Food Eng. Biotechnol. 9:305-309.

Barbieri, S., M.E. Elustondo, and M. Urbicain. 2004. Retention of aroma compounds in basil dried with low pressure superheated steam. J. Food Eng. 65:109-115.

Campbell, N.A. 1990. Biology. Benjamin/ Cummings, Redwood City, CA.

Chen, J.C., M.H. Chiu, R.L. Nie, G.A. Cordell, and S.X. Qiu. 2005. Cucurbitacins and cucurbitane glycosides: Structures and biological activities. Nat. Prod. Rpt. 22:386-399.

Danso-Boateng, E. 2013. Effects of drying methods on nutrient quality of basil leaves cultivated in Ghana. Intl. Food Res. J. 20:1569-1573.

Diaz-Maroto, M.C., M.S. Pérez-Coello, and M.D. Cabezudo. 2002. Effect of drying method on the volatilities in bay leaf (Laurus nobilis L.). J. Agr. Food Chem. 50:4520-4524.

Du, X.W., R.B.K. Wills, and D.L. Stuart. 2003. Changes in neutral and malonyl ginsenosides in American ginseng (Panax quinquefolium) during drying, storage and ethanolic extraction. Food Chem. 86:155-159.

Faridah, Q.Z., A.H.A. Abdelmageed, H.A.N. Nor, and Y. Muhamad. 2010. Comparative study of essential oil composition of leaves and rhizomes of Alpinia conchigera Griff. at different post-harvest drying periods. J. Med. Plants Res. 4:27002705. 
Gregory, M.J., R.C. Menary, and N.W. Davies. 2005. Effect of drying temperature and air flow on the production and retention of secondary metabolites in saffron. J. Agr. Food Chem. 53:59695975 .

Hallström, A. and R. Wimmerstedt. 1983. Drying of porous granular materials. Chem. Eng. Sci. 38:1507-1516.

Hwang, C.R., S.H. Lee, G.Y. Jang, I.G. Hwang, H.Y. Kim, K.S. Woo, J. Lee, and H.S. Jeong. 2014. Changes in ginsenoside composition and antioxidant activities of hydroponic cultured ginseng roots and leaves heating temperature. J. Ginseng Res. 38:180-186.

Jeffrey, C. 1978. Cucurbitaceae, p. 115-117. In: V.H. Heywood (ed.). Flowering plants of the world. Oxford Univ. Press, Oxford, UK.

Krieger, R. 2001. Handbook of pesticides toxicology. Academic Press, San Diego, CA.

Lee, D.H., G.B. Iwanski, and N.H. Thoennissen. 2010. Cucurbitacin: Ancient compound shedding new light on cancer treatment. Sci. World J. 10:413418.

Liu, D.L., M. An, I.R. Johnson, and J.V. Lovett. 2003. Mathematical modelling of allelopathy. III. A model for curve-fitting allelochemical dose responses. Nonlinearity Biol. Toxicol. Med. 1:37-50.

Mashela, P.W. 2002. Ground wild cucumber fruit suppress numbers of Meloidogyne incognita on tomato in microplots. Nematropica 32:13-19.

Mashela, P.W., Z.P. Dube, and K.M. Pofu. 2015. Managing the phytotoxicity and inconsistent nematode suppression in soil amended with phytonematicides, p. 147-173. In: M.K. Meghvansi and A. Varma (eds.). Organic amendments and soil suppressiveness in plant disease management. Springer Intl. Publ., Heidelberg, Germany.

Mashela, P.W., D. De Waele, and K.M. Pofu. 2011. Use of indigenous Cucumis technology as alternative to synthetic nematicides in management of root-knot nematodes in low input agricultural farming system: A review. Sci. Res. Essays 6:6762-6789.

Morris, S.E., N.W. Davies, P.H. Brown, and T. Groom. 2006. Effect of drying conditions on pyrethrins content. Ind. Crops Prod. 23:9-14.

Mphahlele, R.R., P.W. Mashela, and K.M. Pofu. 2012. Post harvesting fruit decayinducing pathogen in medicinally important Cucumis species indigenous to South Africa. Afr. J. Agr. Res. 6:3786-3791.

Mudau, F.N. and W. Ngezimana. 2014. Effect of different drying methods on chemical composition and antimicrobial activity of bush tea (Athrixia phylicoides). Intl. J. Agr. Biol. 16:1011-1014.

Müller, J. and A. Heindl. 2006. Drying of medicinal plants, p. 237-252. In: R.J. Bogers, L.E. Craker, and D. Lange (eds.). Medicinal and aromatic plants. Springer, Dordrecht, The Netherlands.

Novák, I., L. Sipos, Z. Kókai, K. Szabó, Z.S. Pluhár, and S.Z. Sárosi. 2011 . Effect of the drying method on the composition of Origanum vulgare L. ssp. hirtum essential oil analysed by GC-MS and sensory profile method. Acta Aliment. 40:130-138.
Phillips, R.C., D.L. Chamberlain, and F. A. Ferguson. 1960. High-temperature synthesis of new thermally-stable chemical compounds. Wright-Patterson Air Base, Dayton, $\mathrm{OH}$.

Radünz, L.L., E.C. Melo, P.A. Berbert, L.C.A. Barbosa, R.H.S. Santos, and R.P. Rocha. 2003. Influence of drying air temperature on the amount of essential oil extracted from guaco (Mikania glomerata Sprengel). J. Storage 28:41-45.

Rocha, R.P., E.C. Melo, and L.L. Radünz. 2011. Influence of drying process on the quality of medicinal plants: A review. J. Med. Plants Res. 5:7076-7084.

Salisbury, F.B. and C.W. Ross. 1992. Plant physiology. 4th ed. Wadsworth, Belmont, CA.

Shadung, K.G., P.W. Mashela, V.L. Mulaudzi, M.S. Mphosi, and I. Ncube. 2015. Optimum harvest time of Cucumis africanus fruit using concentration of cucurbitacin B as a maturity standard. J. Agr. Sci. 7:181-186.

Thies, J.A., J.J. Ariss, R.L. Hassell, S. Olson, C.S. Kousik, and A. Levi. 2010. Grafting for management of southern root-knot nematode, Meloidogyne incognita, in watermelon. Plant Dis. 94:1195-1199.

Van Wyk, B., F. Heerden, and B. Outshoorn. 2002. Poisonous plants of South Africa. Briza Publ., Pretoria, South Africa.

Van Wyk, B.E. and M. Wink. 2012. Medicinal plants of the world: An illustrated scientific guide to important medicinal plants and their uses. Briza Publ., Pretoria, South Africa. 